\title{
ANALISIS ELEMEN PEMBENTUK RUANG PADA CUSTOMER SERVICE UNIVERSITAS POTENSI UTAMA
}

\author{
Siti Indah Lestari \\ Prodi Desain Interior \\ Fakultas Seni dan Desain Universitas Potensi Utama Medan \\ Indah.ayangjelek@gmail.com
}

\begin{abstract}
ABSTRAK
Ruangan merupakan tempat ataupun wadah yang memiliki nilai timbal balik yang sangat kuat serta tempat orang melakukan interaksi yang memberikan dampak reaksi dan aksi. Aksi dan reaksi manusia bisa dipengaruhi oleh elemen pembentuk ruangnya, elemen pembentuk ruang dapat menciptakan suasana dan karakter pada ruangan tersebut. Pada studi kasus ini ruangan yang akan di bahas yakni Customer Service Universitas Potensi Utama dimana merupakan tempat melayani pihak internal Universitas dan eksternal Universitas. Pengaruh suasana ruang pada Customer Service dapat memberikan kepuasan dalam menyelesaikan masalah dengan memuaskan pelayanan yang diberikan termasuk menerima keluhan atau masalah yang sedang dihadapi. Pada penelitian ini bertujuan mengidentifikasi elemen pembentuk ruang customer service Universitas Potensi Utama yang dapat mempengaruhi reaksi dan aksi pada pengguna ruang tersebut. Pada penelitian ini metode yang digunakan yaitu metode kualitatif, metode ini sebagai landasan penelitian yang dapat menghasilkan data deskriptif dari perilaku orang yang mengamatinya baik berupa lisan dan tulisan. Adapun bentuk penelitian yang digunakan adalah penelitian deskriptif, dimana jenis penelitian ini menjabarkan berupa fenomena-fenomena yang ada pada ruang lingkup studi penelitian tersebut baik yang bersifat alamiah maupun buatan. Fenomena ini banyak memiliki rupa seperti: kegiatan/aktivitas, karakteristik, perubahan serta fenomena lain yang berhubungan dengan fenomena lainnya.
\end{abstract}

Kata kunci: Customer Service, Elemen, Pembentuk, Ruang, Suasana

\begin{abstract}
The room is a place or container that has a very strong reciprocal value as well as a place for people to interact that gives an impact on reactions and actions. Human actions and reactions can be influenced by the elements forming the space, forming elements of space can create the atmosphere and character in the room. In this case study the room to be discussed is Potensi Utama University Customer Service which is a place to serve the University's internal and external parties. The influence of the atmosphere of the space on customer service can provide satisfaction in solving problems by satisfying the services provided including receiving complaints or problems that are being faced. In this study aims to identify the elements forming the customer service room of the Potensi Utama University that can influence the reactions and actions of those space users. In this study, the method used is a qualitative method, this method as a basis for research that can produce descriptive data from people who observe it using both oral and written. The form of research used is descriptive research, where this type of research describes the phenomena in the study room of this study that both support natural and artificial. This phenomenon has many forms such as: Activities / activities, characteristics, other changing phenomena related to other phenomena
\end{abstract}

Keywords: Customer Service, Space Forming Element, Atmosphere 


\section{PENDAHULUAN}

Universitas Potensi Utama merupakan salah satu Perguruan Tinggi Swasta (PTS) dibawah naungan Yayasan Potensi Utama Medan, Pada pelaksanaannya Universitas Potensi Utama melakukan pelayanan di bagian Customer Service untuk menunjang terlaksananya Pendidikan di Universitas, pihak-pihak yang diberikan pelayanan yakni internal dan eksternal Universitas, untuk itu customer service seharusnya mampu memberikan kenyamanan bagi pengunjungnya yakni dengan memperhatikan elemen pembentuk ruang pada customer service tersebut. Elemen pembentuk ruang ini meliputi lantai, dinding, plafon, berbagai bukaan dan perabot pengisi ruang.

Desain suatu gedung atau bangunan yang sehat akan melahirkan rasa yang aman, nyaman, produktif serta berfikiran positif dan sebaliknya desain yang tidak sehat akan melahirkan perasaan tidak nyaman, merasa tertekan dan selalu berfikiran negatif, dampak yang negatif membuat suasana ruang yang tidak nyaman. ${ }^{1}$

Seorang customer service harus mengerti bahwa pelanggan adalah human yang digerakkan oleh emosi. Jadi seorang customer service yang manusiawi adalah human service yang mampu menjamah pelanggan dalam level emosional, spritual serta visual

Penumbuhan suasana dan ruang dapat memberikan arti dan makna kepada penggunanya yang dapat memberikan arti komunikasi pada setiap prosesnya. Menurut ilmu semiotika terciptanya suatu ruang dapat mengandung tanda-tanda terjadinya komunikasi dengan pengguna ruang atau yang melihat.

Suasana dan kualitas lingkungan ruang merupakan alat input bagi manusia yang akan dikonversi ke manusia menjadi pemahaman dan tingkah laku. Sebaliknya, apabila aktivitas manusia itu mampu memberikan dampak suasana ruang, sehingga kesan yang timbul dominan sebagai latar belakang dari sifat dan aktivitas manusia itu sendiri yang dapat mempengaruhi ruang lingkupnya.

Desain interior itu sendiri merupakan suatu perangkat yang dapat menggambarkan serta menampung aktivitas pengguna yang beraktivitas didalamnya, baik berupa organisasi maupun korporasi. Sehingga kesan yang ditumbulkan tersebut dapat tercipta melalui pengorganisasian unsur-unsur desain interior nya sehingga dapat merangsang kepribadian dan perhatian yang melihatnya, sehingga diamati oleh manusia menjadi nilai yang mampu mempengaruhi terbentuknya image suatu organisasi tersebut.

\section{STUDI LITERATUR}

Ruang interior populer dengan cara mengulas elemen yang terdapat didalamnya. Keberadaan manusia selalu dilingkupi oleh ruang dan melalui ruanglah manusia melakukan pergerakan, melihat, mendengar, merasakan serta mencium bau. Pada ruang tercipta bentuk visual, pencahayaan, skala dan dimensi, berinteraksi menjadi satu kesatuan serta terorganisir oleh unsur-unsur bentuk.

Bentuk interaksi menciptakan suatu tindakan dan aksi kepada penggunanya hal ini memberikan efek timbal balik yang dapat mempengaruhi lingkungannya dan bertindak

\footnotetext{
1 "Analisa tata letak pada ruang komersial study kasus lobby hotel”.Jurnal Proporsi,Vol1 No 2, Mei 2016,118
} 
terhadap lingkungan. Keadaan lingkungan yang berbeda dapat menciptakan tindakan yang berbeda pula bagi setiap orang.

Ruang Customer Service merupakan wadah pada suatu organisasi atau perusahaan untuk saling melakukan aksi dan reaksi, aktivitas ini dapat memberikan persepsi bagi penggunanya baik secara emosional, spritual dan, bahkan, visual. Dari segi emosional dan spritual reaksi ini dapat ditimbulkan dari pelaksanaan pelayanan yang diberikan oleh para karyawan yang menduduki customer service tersebut sedangkan dari segi visual reaksi ini dapat ditimbulkan oleh keberadaan interior yang ada di ruang customer service tersebut.

Desain interior akan mempengaruhi pandangan dan pencitraan terkait dengan suasana hati dan kepribadian manusia. Keberadaan interior ini dapat memberikan kesan yang utama bagi pengunjung suatu perusahaan tersebut serta image utama yang dapat dipersepsi oleh pengunjung. Untuk itu keberadaan elemen pembetuk ruang yang terdapat di ruang customer service haruslah menciptakan suasana ruang yang positif kepada orang yang melihatnya, sehingga penciptaan suatu ruang harus memperhatikan elemen-elemen pembentuk ruangnya sehingga dapat menciptakan hasil yang diharapkan.

Ruang interior dibentuk oleh beberapa bidang dua dimensi, yaitu lantai, dinding,plafon, serta bukaan pintu dan jendela. Apabila salah satu di antaranya tidak ada maka tidak dapat disebut sebagai interior (ruang dalam) karena ruangan tersebut tidak punya plafon maka akan disebut eksterior/ruang luar. Contoh lainnya apabila tidak punya pintu dan jendela maka ruangan tersebut tidak dapat ditempati.

Secara tiga dimensional, terdapat empat elemen dasar pembentuk interior yang terdiri dari tiga bidang dimensional (3D) yang akan membentuk volume (panjang x lebar x tinggi) sebuah ruangan:

- Lantai sebagai bidang bawah,

- Dinding sebagai bidang tengah/penyekat,

- Plafon sebagai bidang atas,

- Berbagai bukaan yang dapat diaplikasikan kedalam tiga bidang dimensional di atas, serta

- Elemen pengisi ruang yang disebut juga perabot atau furnitur, biasanya berwujud kursi, meja, ranjang atau dipan, lemari, lukisan, vegetasi, lampu dan lain-lain 


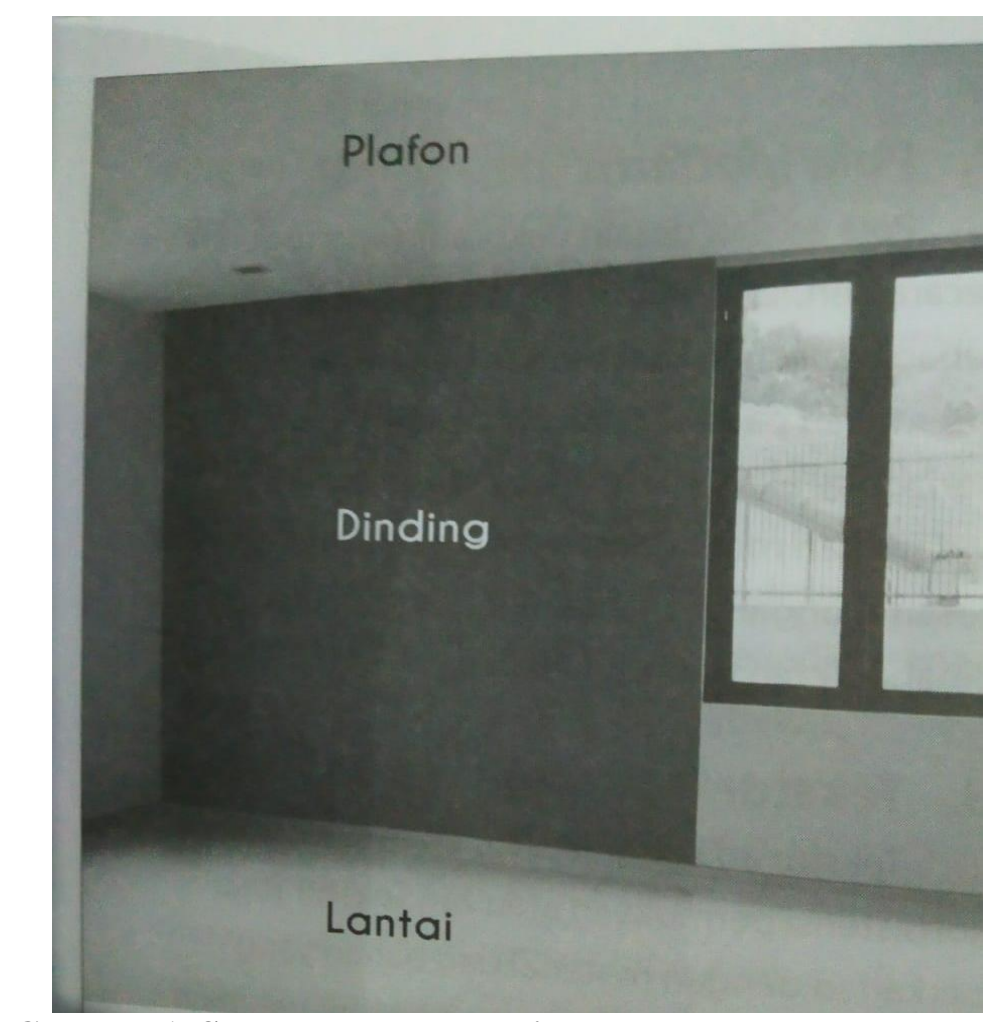

Gambar 1. Susunan beberapa bidang pembentuk ruang

\section{Lantai}

Lantai adalah bidang bawah dari suatu bangunan yang dapat digunakan penggunanya untuk beraktivitas (hidup, bekerja, rekreasi, dan lain-lain). Lantai biasanya terdiri dari beberapa sub lantai sebagai pendukung dan penutup lantai yang memberikan permukaan untuk kenyamanan sirkulasi pergerakan pengguna ruang.

\section{Dinding}

Dinding adalah struktru vertikal, biasanya benbentuk padat, yang membatasi dan melindungi suatu area. Umumnya dinding didesain untuk menggambarkan bentuk sebuah bangunan, mendukung superstruktur, memisahkan ruang dalam bangunan menjadi beberapa bagian, serta melindungi atau menggambarkan ruang di udara terbuka.

\section{Plafon}

Plafon adalah permukaan bidang atas interior yang meliputi batas atas sebuah ruangan. Sebuah plafon umumnya buka elemen struktur, tetapi hanyalah bidang untuk menyembunyikan bagian bawah sturktur lantai atas atau atap.

Menurut Moenir (2008) customer service adalah kegiatan yang dilakukan oleh seseorang atau sekelompok orang yang berlandaskan faktor materialnya melalui sistem, prosedur, dan metode tertentu dalam rangka usaha memenuhi kepentingan orang lain sesuai hak-haknya.

Data yang digunakan pada penelitian ini adalah hasil foto dokumentasi, hasil wawancara oleh pegawai yang menjabat customer service, pihak internal dan pihak eksternal Universitas. 


\section{PEMBAHASAN}

1. Tampak Depan Ruangan Customer Service

Ruangan yang berfungsi sebagai pelayanan pihak internal dan eksternal Universitas, pihak internal disini adalah mahasiswa Universitas Potensi Utama, dimana ruangan ini tempat melakukan aksi dan reaksi seperti melakukan pendaftaran ujian yang berkaitan dengan proses belajar mengajar. Pelayanan bagi pihak eksternal adalah pelayanan dalam hal pendaftaran mahasiswa baru (pmb) serta pelayanan kepada orang tua/wali mahasiswa untuk menanyakan status mahasiswa yang bersangkutan.

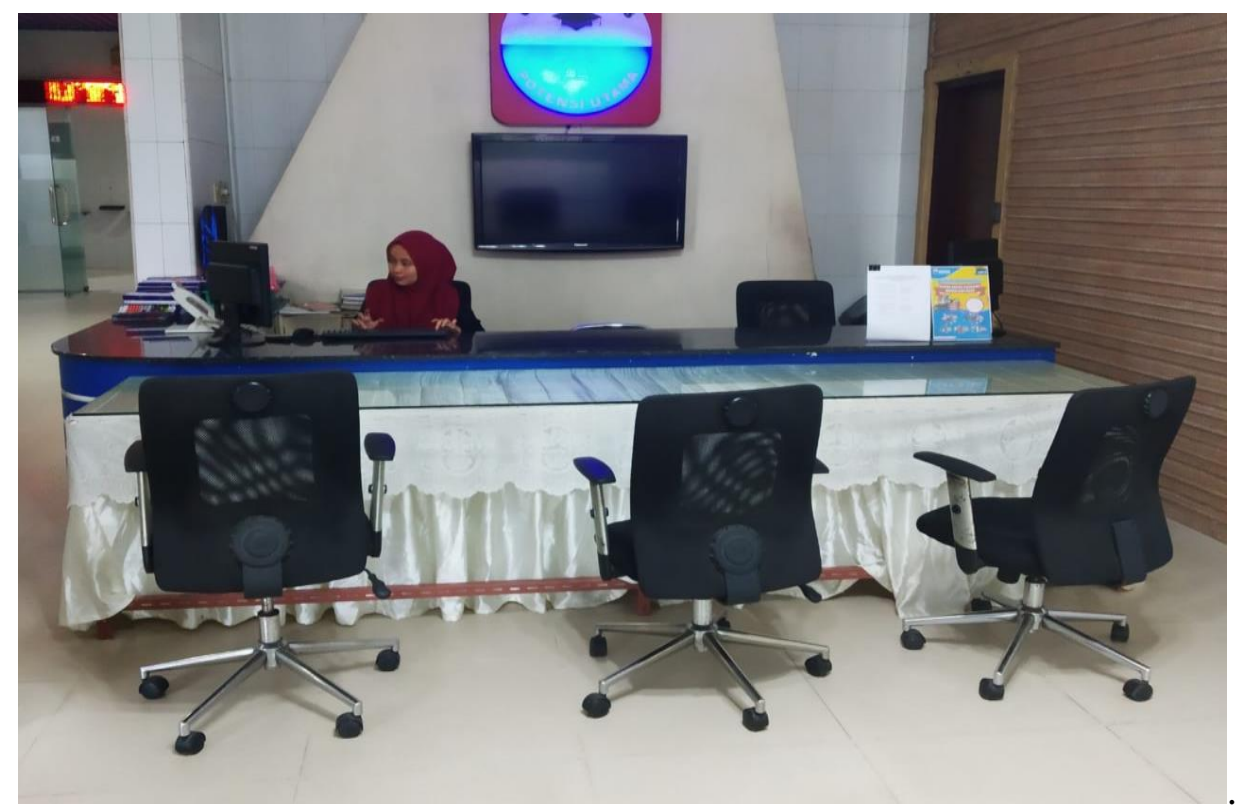

Gambar 2. Tampak Depan Ruangan Customer Service

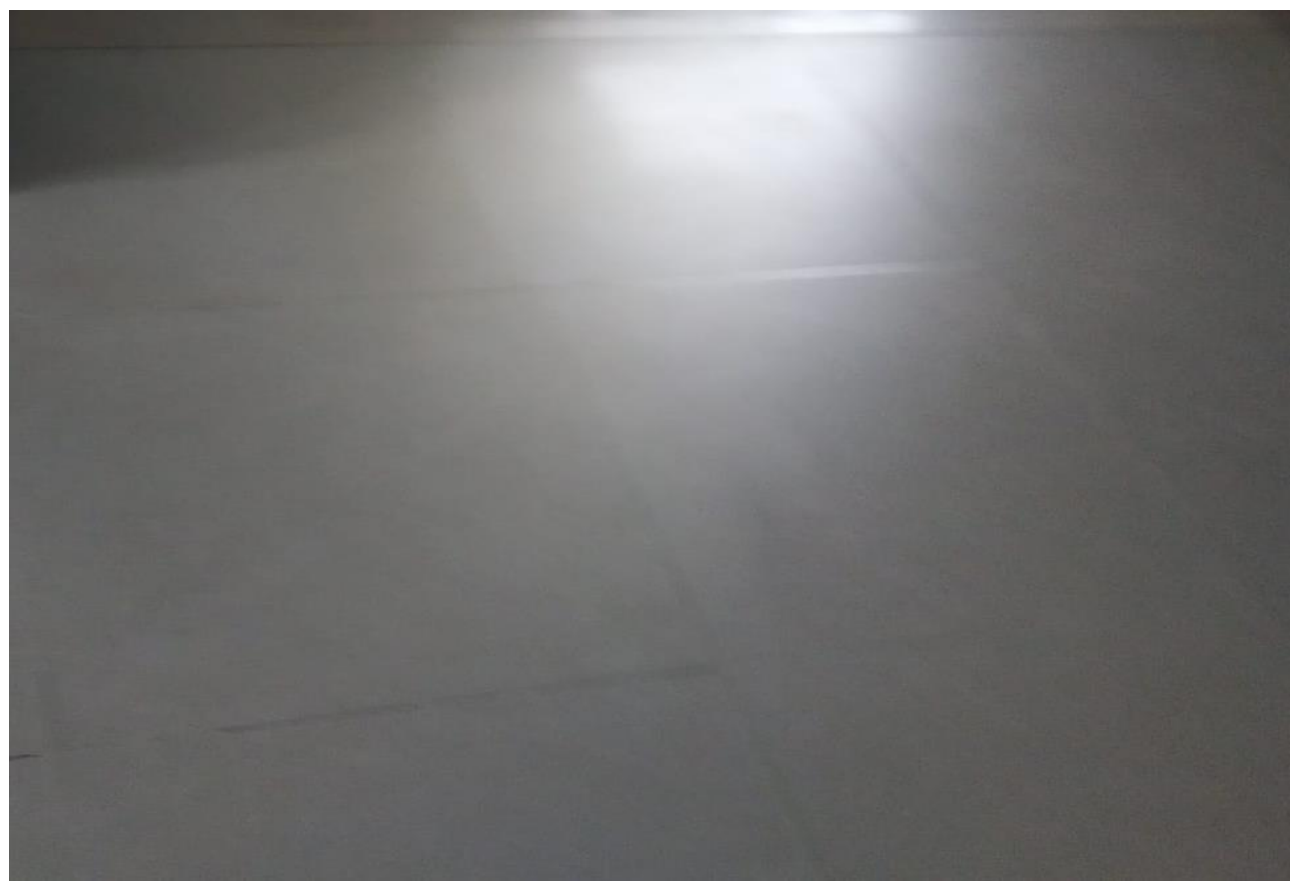

Gambar 3. Lantai Keramik Pada Customer Service 
Bahan : Bahan keramik, memiliki karakterisktik sejuk karena lantai keramik tidak meneruskan panas sehingga suasana yang tercipta adem cocok di aplikasikan di customer service karena memiliki value pengguna yang sangat tinggi.

Warna : Warna cornsilk memiliki karakter yang dekat dengan tanah menciptakan suasana yang aman dan nyaman sehingga mampu memberikan rasa nyaman bagi pengunjung.

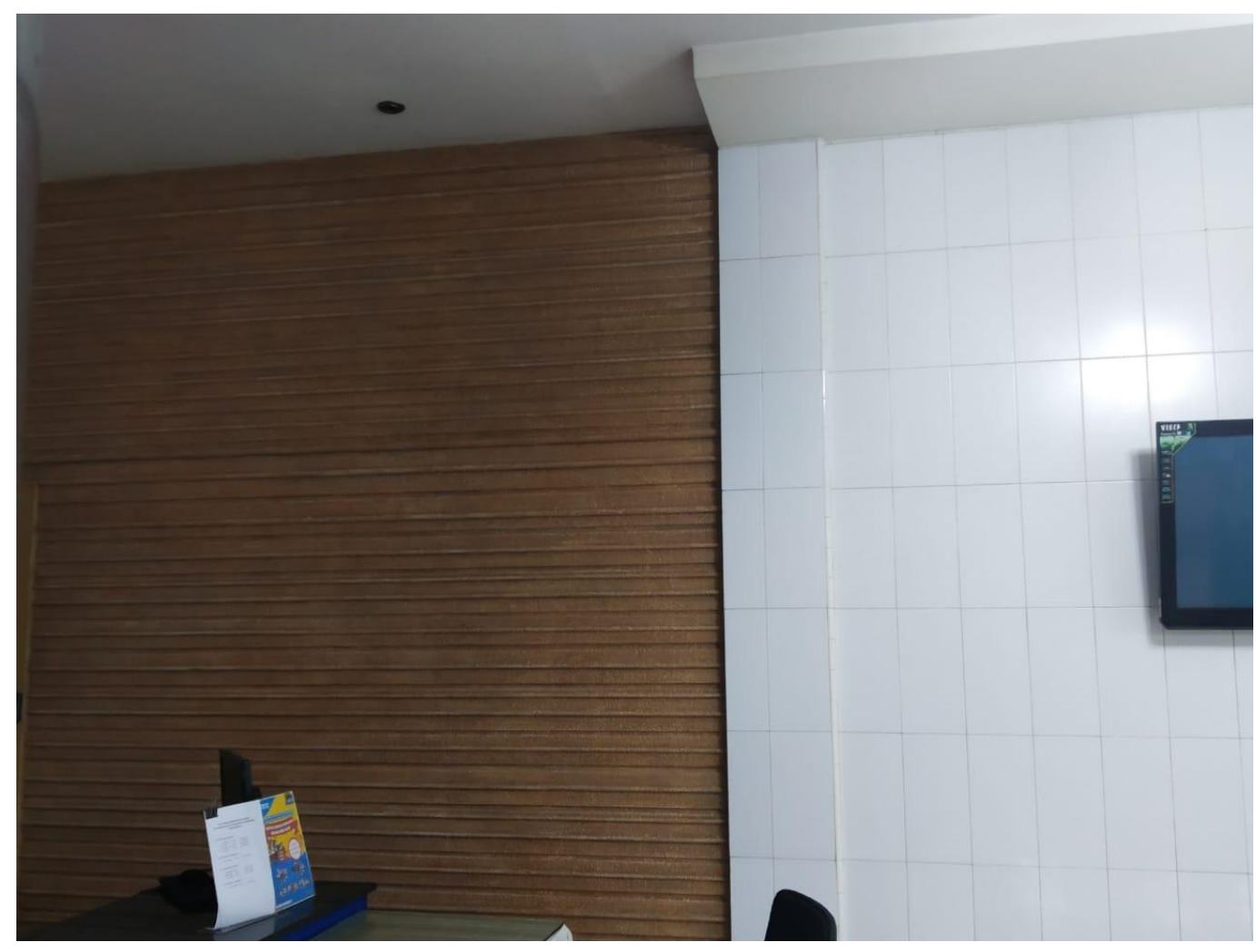

Gambar 4. Sisi Kanan Dinding Customer Service

Pada tampak depan sisi kanan bagian customer service terlihat perpaduan dinding berbahan kayu dan keramik, perpaduan keduanya terlihat tidak serasi sehingga menimbulkan kesan monoton, sebaiknya perpaduan dinding berbahan keramik tersebut berwarna kecokelatan agar selaras dengan dinding berbahan kayu disampingnya dengan memberikan kesana suasana ruang yang adem. 


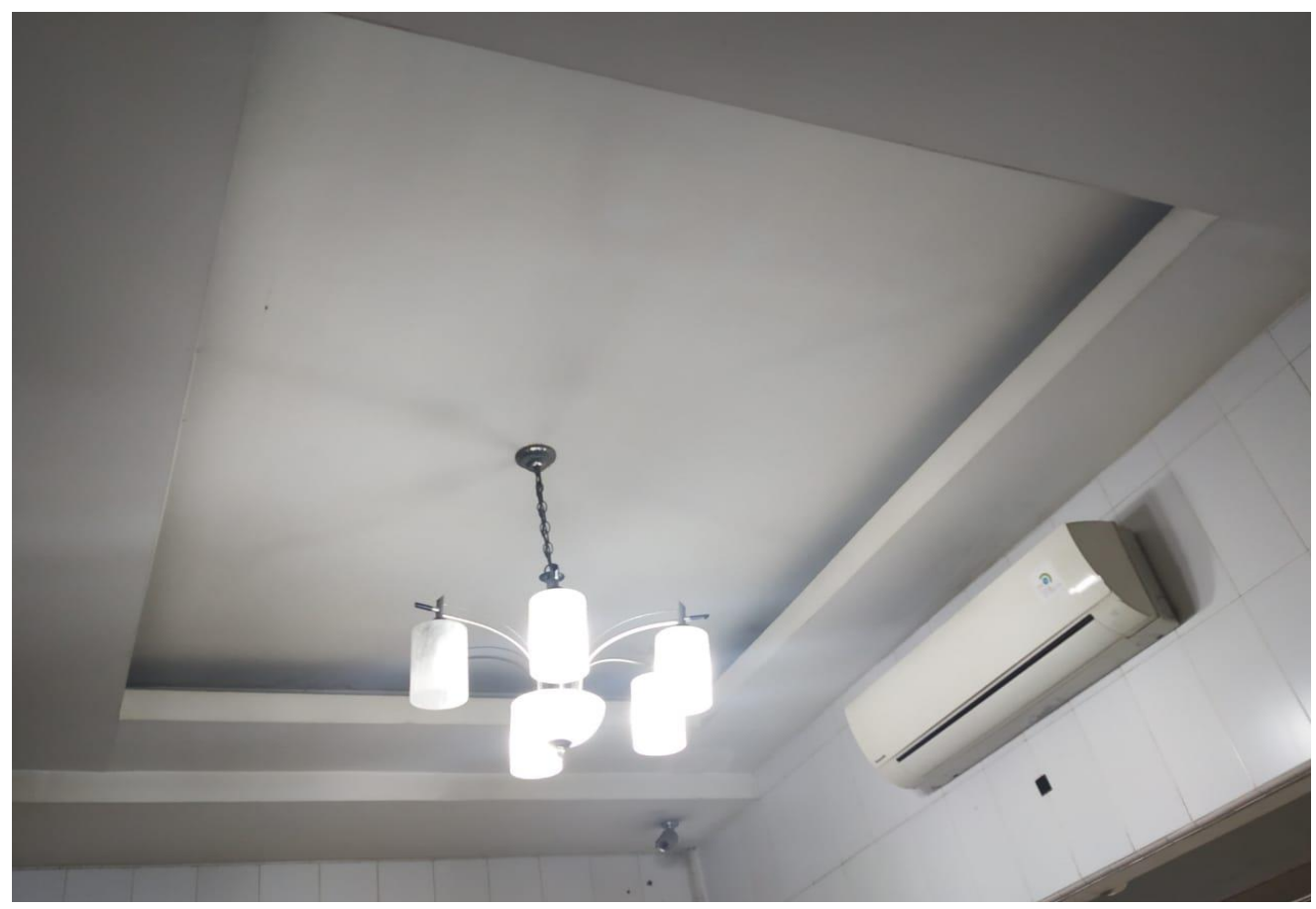

Gambar 5. Plafon Gypsum

Bahan : Plafon yang digunakan yakni plafon gypsum yang dapat memberikan suasana ruang yang rapi, nyaman dan bersih

Warna : Warna yang digunakan yaitu warna putih polos, bersih dan dingin sehingga memberikan kesan yang ringan, selain itu warna putih juga memberikan kesan yang natural dan netral serta memberikan efek visual yang modren.

Pada plafon ini berbentuk plafon GRC yaitu bentuk yang dapat diubah dan disederhanakan baik di kurangi atau di tambahkan tetapi pada plafon jenis ini bentuk awalnya sangat mudah dikenali walaupun sudah dilakukan perubahan. Secara visual plafon ini memberikan kesan yang lebih luas.

2. Tampak Samping lorong Ruangan Customer Service 


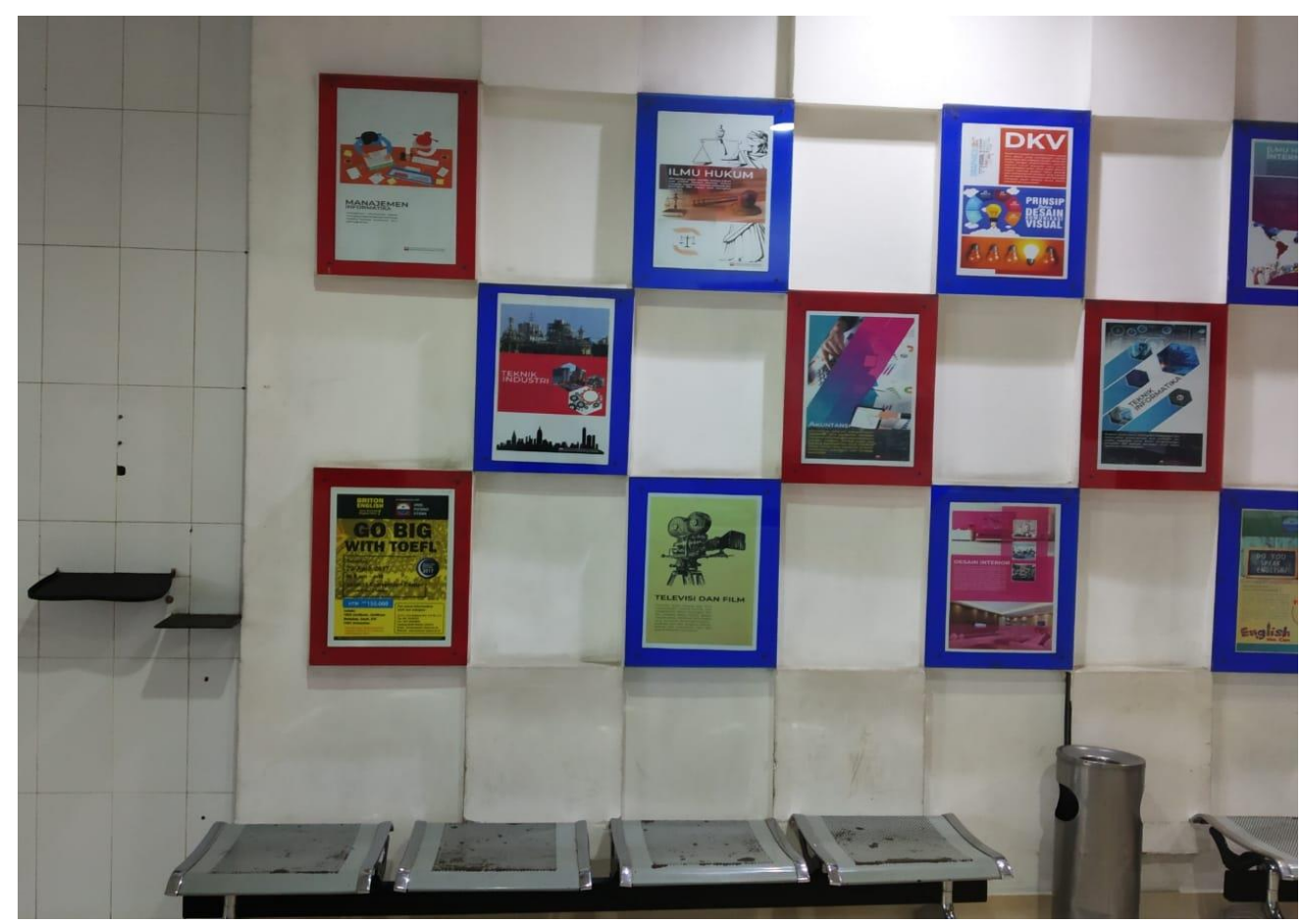

Gambar 6. Sisi Kiri lorong Dinding Customer Service

Pada sisi kiri lorong dinding Customer Service terpajang berbagai gambar yang berkaitan dengan program studi yang ada di Universitas Potensi Utama berlatang belakang berwarna putih, jika dilihat gambar tersebut dipajang tidak beraturan karena letak gambar tidak berurutan sesuai dengan fakultas dan prodi, pada bagian bawah diletakkan tempat duduk stainless yang berfungsi sebagai tempat menunggu, posisi ini menambah kesan yang tidak beraturan pada sisi lorong yang seyogyanya terlihat luas dan luwes dan apabila tempat duduk tersebut di tempati oleh pengunjung maka penampakan gambar di atas nya tidak akan terlihat karena tertutupi oleh yang menduduki kursi tersebut.

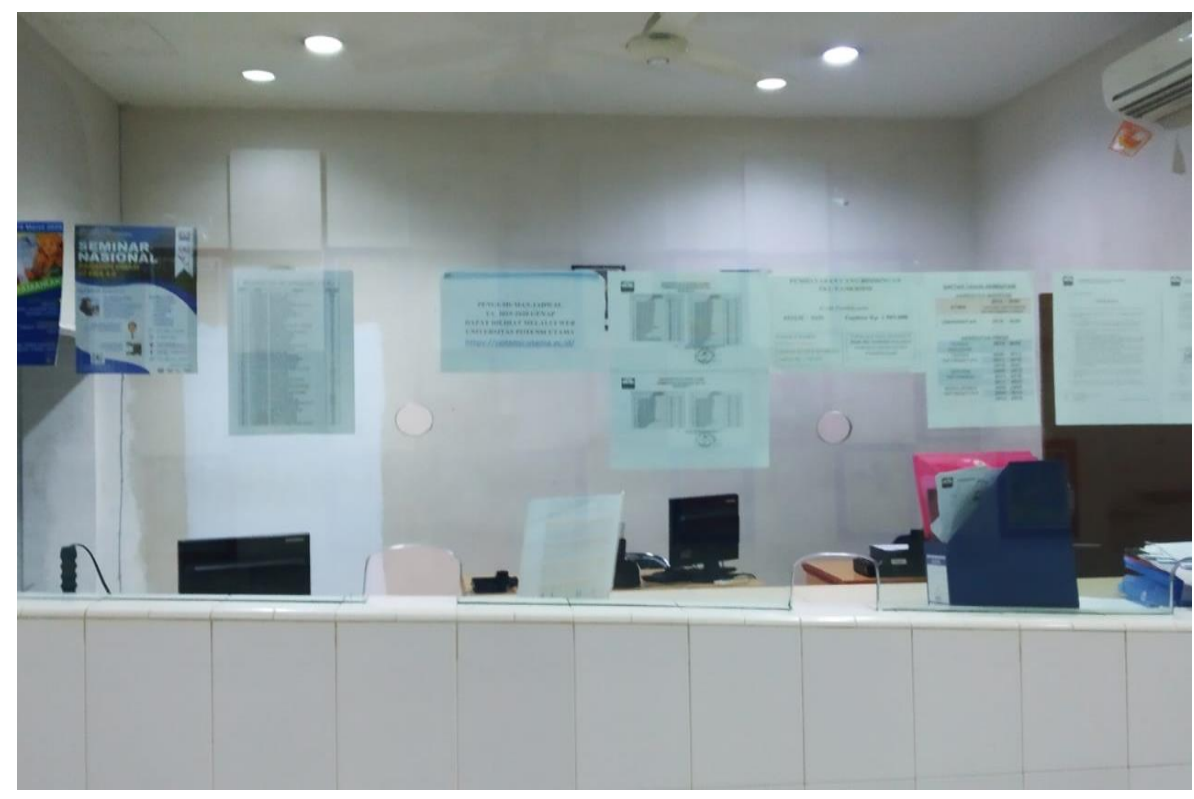

Gambar 7. Pelayanan Kasir Customer Service 
Gambar di atas merupakan tempat kasir melayani pembayaran yang berkaitan dengan proses belajar mengajar mahasiswa, terlihat dibatasi dinding kaca dengan ukuran \pm $12 \mathrm{~mm}$ dengan 4 lubang tempat pelayanan dengan perpaduan dinding keramik, terlihat pada kaca pelayanan banyak menempel berbagai macam pengumuman yang menyebabkan pemandangan yang kurang rapi, selayaknya ruang customer service

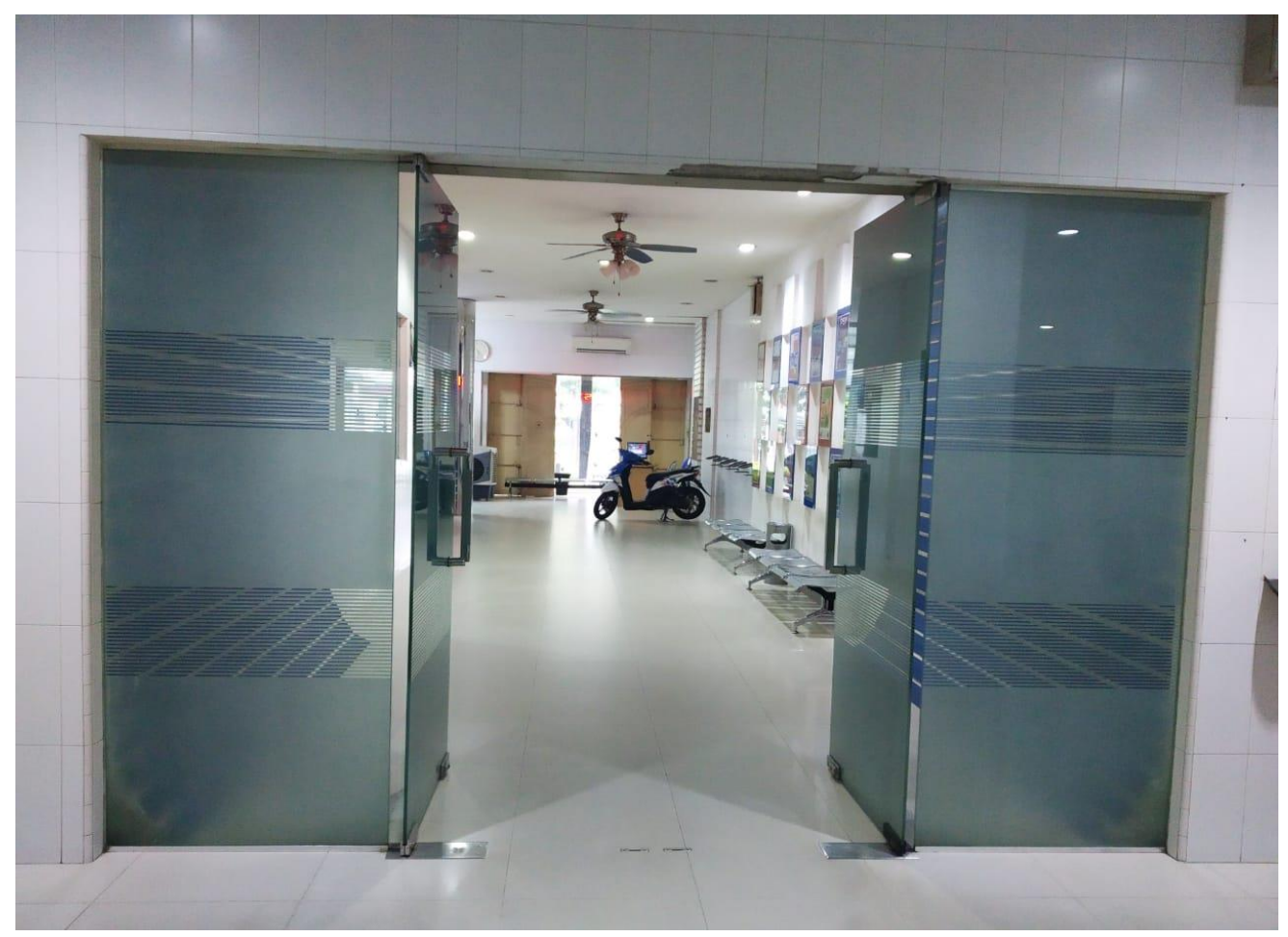

Gambar 8. Pintu pembatas antara ruang customer service dan loby

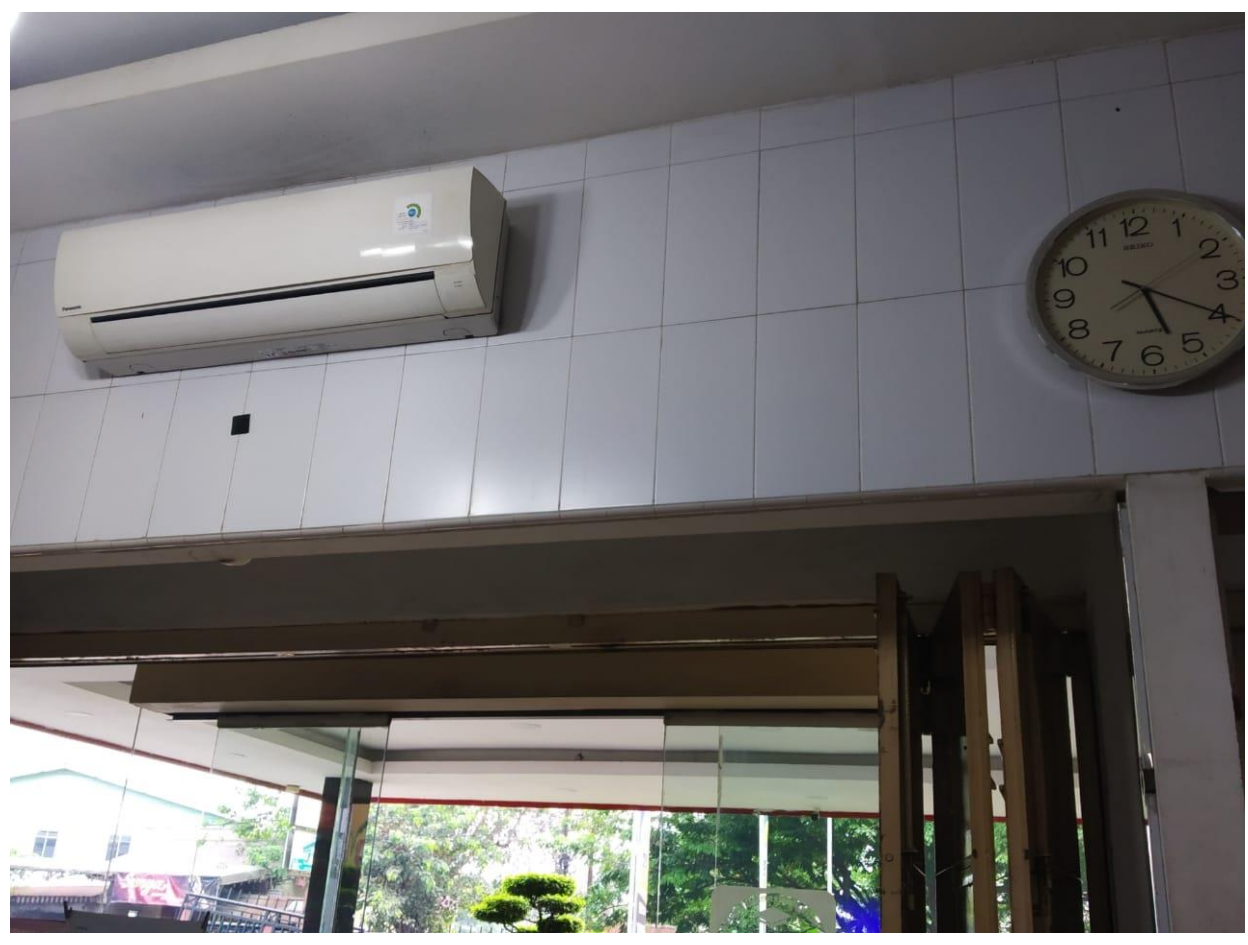

Gambar 9. Pendingin Ruangan (AC) 


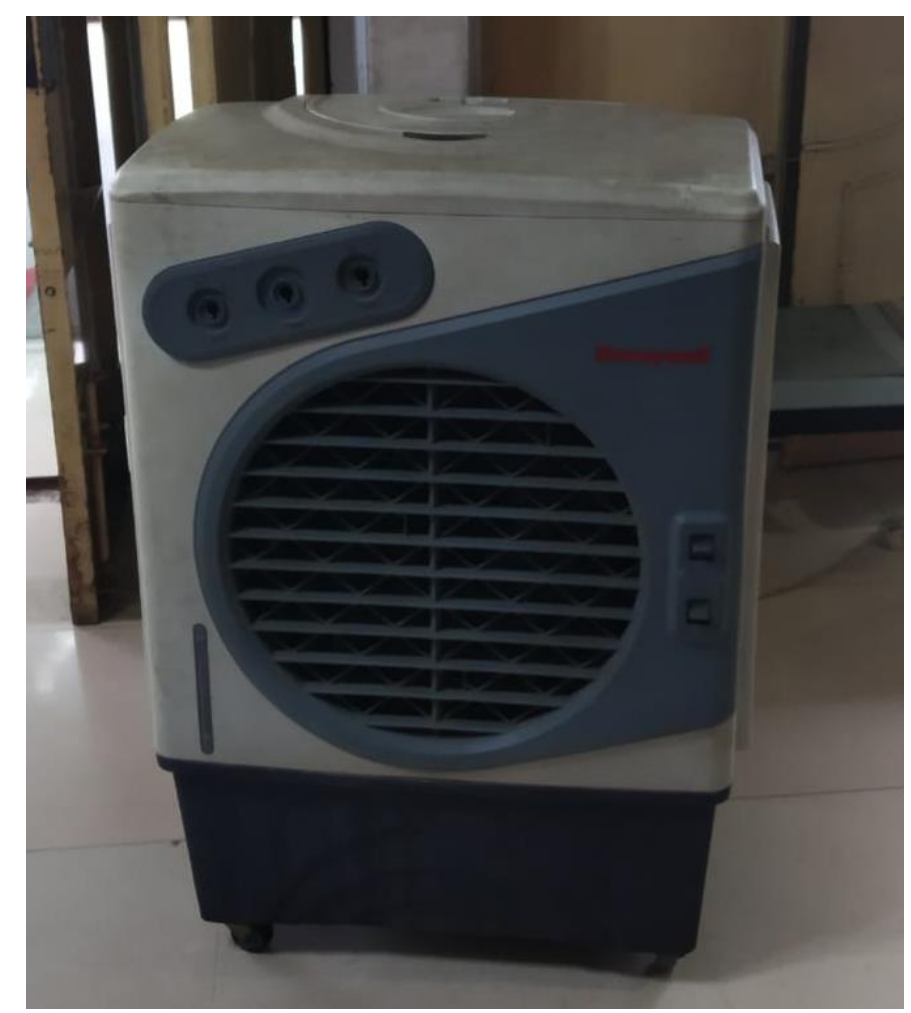

Gambar 10. Pendingin Ruangan (Kipas)

Selain elemen-elemen pembentuk ruang seperti plafon, dinding dan lantai tersedianya pendingin ruangan seperti $\mathrm{AC}$ juga dapat memberikan suasana yang nyaman pada ruangan tersebut dan hal ini sangat menunjang terciptanya ruangan yang asri dimana bila diketahui ruang customer service merupakan ruangan yang sangat sering dikunjungi karena posisi nya yang di depan dan menjadi pusat perhatian dan menjadi pusat pelayanan dari pihak internal maupun eksternal Universitas.

Menurut J. Pamudji Suptandar, bahwa bahan yang dipakai akan berpengaruh terhadap pembentukan suasana ruang, antara lain :

a. Lantai : Bahan penutup lantai yang memberi suasana hangat, misanya: karpet, parket, jalur kayu, serat kayu, dan sebagainya. Bahan penutup lantai yang memberi suasana dingin/sejuk. misalnya: marmer batuan alami lantai keramik. Bahan marmer, mempunyai karakteristik permanen dan kaku. Penggunaan bahan marmer sebagai penutup lantai memberikan suasana yang indah dan sejuk (nyaman). Bahan keramik tile. mempunyai karakteristik indah, sejuk, dan luas. Bahan kayu, mempunyai karakteristik alamiah, kedap suara, tahan lama, dan penghantar hangat yang baik. Suasana yang tercipta adalah suasana hangat, alami, dan indah.

b. Dinding: Seperti Batu: Bermacam-macam batu alam (batu kali. batu bata, batako dan sebagainya). Memberi kesan dan suasana relief mirip dengan dinding goa sehingga terasa adanya pendekatan dengan alam indah hangat dan merupakan sebuah usaha untuk menciptakan suasana dan unsur yang berlainan. Cat: Penggunaan bahan cat sebagai penutup dinding memberi suasana yang bersih, luas, dan rapi. Disamping itu juga tergantung warna yang digunakan. Fiberglass: Penggunaan bahan fiberglass pada ruangmemberikan suasana ruang yang luas, bersih, modern, dan rapi. Gelas : Cermin, kaca 
(kaca bening, rayben, kaca es) memberikan suasana indah dan modern, memperluas kesan ruang dan terang karena bahan kaca dapat merefleksi cahaya.

c. Plafon : Bahan yang dapat digunakan sebagai plafon bermacam-macam seperti kayu, gypsum, kaca, triplek, dan sebagainya. Bahan tripleks dan gypsum dapat memberikan suasana yang rapi, bersih, dan sederhana. ${ }^{2}$

\section{KESIMPULAN}

Elemen pembentuk ruang seperti lantai, dinding dan plafon harus menimbang kenyamanan pengguna, sehingga terbentuk ruangan yang menyenangkan dan nyaman karena selain pelayanan yang harus ditonjolkan pada customer service suasana dan elemen pembentuk ruang juga mempunyai nilai yang harus diperhatikan pada suatu ruangan, faktanya jika seseorang mengunjungi suatu tempat yang pertama kali di lirik bukanlah pekerja yang melayani tetapi suasana yang ada di ruangan tersebut.

Sejatinya unsur emosi pada ruang merupakan faktor utama yang memberikan daya bujuk yang halus namun menggoda, melalui unsur-unsur bentuk yang menarik perhatian yang melihatnya ataupun sentuhan pada tekstur yang menyenangkan pada permukaan kulit.

Analisis ini diharapkan mampu memberikan gambaran rencana kedepan bagi pemilik maupun pengelola Universitas Potensi Utama jika harus meredesain ruang customer service, sehingga mampu memberi dampak positif dari segi desain dan fungsinya sehingga dapat menjawab kebutuhan pengguna saat berada di ruangan customer service.

\section{DAFTAR PUSTAKA}

[1] Andie Arief Wicaksono, Endah Trisnawati. (2014). Teori Interior.Griya Kreasi

[2] Desain Interior Universitas Kristen Petra. 2014. JURNAL INTRA Vol. 2, No. 2, 414420.

[3] Desain Interior Institut Teknologi Sepuluh Nopember (ITS). 2014. JURNAL SAINS DAN SENI POMITS Vol. 3, No.1, 2337-3520

[4] Praktisi Desain Interior 2004. DIMENSI INTERIOR Vol. 2, No.1, 51-65

[5] Desain Interior Universitas Kristen Petra. 2013. JURNAL INTRA Vol. 1, No. 1, 1-7

[6] Saputra, Ryan Budhi. (2015) Teori dan Konsep Perancangan Ruang Dalam. [Online]. Tersedia: https://1219251008ketutryanbudhisaputra.wordpress.com /2015/03/10/teoridan-konsep-perancangan-ruang-dalam/ 10 Maret 2015.

[7] Desain Interior Universitas Kristen Petra.2013.JURNAL INTRA Vol 1, No.1, 1-7.

\footnotetext{
2 "Pengaruh Aksesoris dan Elemen Pembentuk Ruang terhadap Suasana dan Karakter Interior Lobi Hotel Artotel Surabaya”.Jurnal Intra,Vol1 No 1, 2013,1-7
} 